\title{
The Secret Lives of Pets: Trends from the 2020-2021 Year in Review Reports of the Academic Business Library Directors
}

\author{
GREG FLEMING \\ University of Chicago, Chicago, IL \\ gdf@uchicago.edu
}

\begin{abstract}
A summary of Year in Review reports of members of the Academic Business Library Directors group (ABLD). Themes include new and ongoing initiatives in libraries, library collections, organizational change in libraries and member business schools and changes in library spaces.
\end{abstract}

Keywords academic business libraries, library trends, organizational changes, new initiatives, business schools, Academic Business Library Directors (ABLD)

\section{Introduction}

The Academic Business Library Directors (ABLD) group meets annually in the spring. This is normally a face-to-face meeting, but the meeting for 2021 was held online during April and May due to the COVID19 pandemic. The theme was "The Secret Lives of Pets," a reference to the fact that most members had been working from home during the COVID-19 pandemic. A year in review session that summarizes members' annual reports has been a feature of the meeting for many years, and one was held online in May of 2021. Reports covered issues and events in members' libraries and business schools for the period April 2020 to March 2021. This year's reports also included a section devoted to the effects of the COVID19 pandemic.

\section{Business Libraries Face COVID-19}

The COVID-19 pandemic was in its early stages at the beginning of April 2020. Most universities shut down their campuses and moved to online instruction for Spring 2020. Members' experiences were very different as the pandemic continued. Some service changes were the same for most members, such as providing research consultations via Zoom or other conferencing software. Most libraries offered services for checking out books through scheduled pick-ups by patrons. Many members activated HathiTrust Emergency Temporary Access Service (ETAS). This allowed libraries to turn on access to materials in HathiTrust that are still in copyright, with the requirement that the physical book cannot be loaned. This was very popular, as many students were far from campus, so limiting access to print books was not a hardship. UC Berkeley leveraged this service by buying two copies of requested textbooks. One copy was added to the collection while the other was destructively scanned and uploaded to HathiTrust. This allowed them to add titles to ETAS quickly (ABLD, 2021, p. 21).

Many libraries launched new services as a result of the shift to online learning. Chat reference service was implemented at Alabama (ABLD, 2021, p. 3). Ohio State expanded chat service hours by using students for part of the day (ABLD, 2021, p. 21). Southern Methodist (SMU) turned on a proactive 
Ticker: The Academic Business Librarianship Review, 6:2 (2021)

https://doi.org/10.3998/ticker.1940

(C)2021 Greg Fleming

feature in their chat service; a chat box popped up after a patron spent a certain amount of time on their web site, and this increased usage significantly (ABLD, 2021, p. 105). Michigan added a separate chat channel for course reserves but found the usage much less than anticipated (ABLD, 2021, p. 76). Cornell instituted an online classroom service called Virtual Air Traffic Control. Library staff assisted faculty with details during online classes, including managing breakout rooms and answering technical support questions (ABLD, 2021, p. 47). Carnegie Mellon implemented a controlled digital lending service for course reserves. This was similar to the ETAS model, and they provided access to scanned versions of books while the print copy was kept inaccessible to users (ABLD, 2021, p. 30). Northwestern librarians helped facilitate an online practicum, Foundations of Online Teaching. This was attended by hundreds of faculty members, and feedback was overwhelmingly positive (ABLD, 2021, p. 91).

The mode of classroom instruction in Fall 2020 varied for members' institutions. Twenty-seven members reported on this. Eighteen moved forward with hybrid classes with some students in person and others online. Eight schools offered online classes only. Purdue was the only school that reported full inperson classes. Arizona State was already planning to hold orientation activities for returning students who had never experienced campus in-person (ABLD, 2021, p. 6).

Most libraries opened for some level of service in Summer 2020, but six libraries remained closed to patrons at the time reports were submitted. Study space with seat reservations was the most common model, with limited access to other parts of the library. Most libraries moved course reserves completely online, but Babson, Cornell and Penn State reported doing some print reserves (ABLD, 2021, pp. 7, 47, 99). Access to books was restricted in many cases, due to the requirement to sequester books that were made available in HathiTrust ETAS.

The return to on-site work was split almost evenly among members who reported it. Twelve were working in some sort of hybrid remote and on-site arrangement. Thirteen were still entirely remote. No member had made a return to full-time on-site work at the time of the reports. Planning for Fall 2021 was still vague for most members, but many reported that their schools were planning to hold in-person classes and for most staff to be back on campus.

\section{New and Ongoing Initiatives}

Diversity, equity and inclusion (DEI) were major themes of members' reports. A number of libraries hired or were in the process of hiring high-level leadership positions related to DEI. Carnegie Mellon had developed a strategic plan around DEI and began its implementation in Fall 2020 (ABLD, 2021, p. 32). Cornell began several initiatives, including focusing on acquiring books by diverse authors and developing a strategy to create an inclusive environment in the Management Library (ABLD, 2021, p. 48). Ohio State encouraged all library faculty to draft a DEI-related goal for 2021 and had many discussions around advancing social justice through the library collections (ABLD, 2021, p. 93). Arizona State hired a consultant to conduct a DEI audit (ABLD, 2021, p. 6). Boston University and Maryland had anti-racism events and statements after the events during the summer of 2020, and UCLA formed a library-wide antiracism committee (ABLD, 2021, pp. 11, 27, 71).

Open access continues to be an area in which libraries are expanding services. Transformative or Read and Publish agreements have been a recent approach by publishers to expand access. A library gets access to a defined set of journals and authors can publish open access in those journals without having to pay article processing charges. Ohio State entered a Read \& Publish agreement with Taylor \& Francis, and Carnegie Mellon did so with Elsevier, Cambridge University Press and the Association for Computing 
Ticker: The Academic Business Librarianship Review, 6:2 (2021)

https://doi.org/10.3998/ticker.1940

(C)2021 Greg Fleming

Machinery (ABLD, 2021, pp. 31, 93). Carnegie Mellon and Yale also joined a PLoS ONE initiative that allows campus authors to publish in the open access journal without paying article process charges (ABLD, 2021, pp. 31, 135). Maryland joined TOME, an open monograph project, and will sponsor three titles written by Maryland faculty (ABLD, 2021, p. 71).

Michigan State began a pilot project of "Bibliometrics as a Service." A librarian creates reports for promotion and tenure reviews comparing MSU faculty to those at peer institutions. These were well received by business school management. (ABLD, 2021, p. 82). Yale introduced a new software tool called the Yale Library Emulation Viewer. This tool allows researchers to run CD-ROMs that require obsolete hardware using links in the library catalog. The software emulation runs in a web browser, removing many obstacles to access to older data sources (ABLD, 2021, p. 135). Librarians at Penn began participating in the review of proposals from faculty for the Dean's Research Fund. This gave them valuable insights into current faculty research interests, and they were able to put these insights to use to inform collection work and engagement with faculty (ABLD, 2021, p. 96). Washington University is collaborating with St. Louis University, the University of Missouri-St. Louis, and the Federal Reserve Banks of Kansas City and St. Louis to establish a Census Research Data Center on the WashU campus. This center will offer researchers access to sensitive government data that can only be used in these centers (ABLD, 2021, p. 117). Researchers currently have to travel to Kansas City or Columbia, Missouri for access to these data.

\section{Library Organization}

The pandemic affected library staffing at many institutions. Official hiring freezes were in place at many members, while others reported chills, meaning all vacancies were reviewed before they were allowed to be posted. Boston University and Carnegie Mellon were the only members who reported staff layoffs (ABLD, 2021, pp. 10, 32). Penn, Purdue, and Vanderbilt were able to hire new business librarians in spite of other restrictions on hiring (ABLD, 2021, pp. 97, 103, 130)

Library directors announced their retirements or resignations at Chicago, Indiana, Washington University, the University of Washington, and Vanderbilt (ABLD, 2021, pp. 39, 66, 118, 122, 130). Searches were underway, but no replacements had been named yet. Indiana will welcome a new university president and provost in 2021 (ABLD, 2021, p. 66).

New leadership positions related to diversity, equity and inclusion were created at several libraries. UCLA anticipated hiring a director that reports directly to the university librarian (ABLD, 2021, p. 28). Illinois, Michigan State, and Ohio State were also recruiting. Purdue hired an associate dean for organizational development, diversity, and inclusion. Purdue also had a reorganization that removed divisions based on disciplines, and now all librarians report to one department head (ABLD, 2021, p. 103). Penn also reorganized after a senior level retirement (ABLD, 2021, p. 97).

\section{Physical Spaces}

"Getting dusty, I imagine." (ABLD, 2021, p. 114)

Reports had much less content on physical spaces this year, which was unsurprising. Many members reported that they had not been in their physical space during the year. Renovation work went forward in many libraries, however. The University of British Columbia (UBC) took advantage of the library closure to store office materials in spaces that are usually open to patrons (ABLD, 2021, p. 16). Michigan State got new carpet and furniture (ABLD, 2021, p. 83). Construction projects at Vanderbilt and Yale will affect 
Ticker: The Academic Business Librarianship Review, 6:2 (2021)

https://doi.org/10.3998/ticker.1940

(C)2021 Greg Fleming

library access when students return. Study space will be closed at Yale, and while Vanderbilt's library renovation is complete, the surrounding building will be renovated and closed entirely during school breaks (ABLD, 2021, pp. 130, 135). Virginia lost some staff space to business school IT staff, but it was unclear whether that is permanent (ABLD, 2021, p. 127). Dartmouth closed its music and physical sciences libraries (ABLD, 2021, p. 50).

Other renovation projects were cancelled or postponed. Staff spaces were scheduled to be renovated at Cornell and Penn State, but both were postponed (ABLD, 2021, pp. 48, 100). Columbia is building a new business school campus, but it was unclear where the library will fit in the new space at the time of their report (ABLD, 2021, p. 45).

\section{Collections}

The COVID pandemic caused many issues with collections and databases. One major issue for members was adapting access to terminal-based databases such as Bloomberg with physical libraries. While Bloomberg did end up providing an alternative, other services were not as flexible. Cornell offered mediated access to SDC Platinum and Bloomberg via Zoom sessions until Bloomberg Disaster Recovery was launched (ABLD, 2021, p. 47). Librarians at Illinois initially did all searching and downloading of data from SDC Platinum, but the size of the requests became burdensome. They were able to set up a Windows remote desktop server that allowed users to access the database themselves. (ABLD, 2021, p. 89). Columbia and UBC also instituted services that allowed remote connections to SDC Platinum and Datastream (ABLD, 2021, pp. 14, 45).

Collection budgets were a major theme of reports. Most members reported flat or reduced budgets. Although many vendors kept price increases low or flat, many members reported they were still required to cancel journal and database subscriptions. Chicago, Indiana, and the Virginia Research Libraries group (which includes the University of Virginia and William \& Mary) broke up their Big Deal packages with Elsevier, with significant cost savings (ABLD, 2021, pp. 40, 66, 127). Chicago joined RapidILL to offset the loss of access. This service automates interlibrary loan requests and can fulfill them in as little as thirty minutes.

Ohio State reported having issues around licensing. Many offices were interested in using library resources for commercial activities. The campus is pushing towards more commercialization, so it is anticipated that this will continue to be a problem (ABLD, 2021, p. 94). The University of Washington is beginning to document vendors that do not comply with accessibility guidelines. The library had not had reports of any of their vendors, but anticipated it happening in the future (ABLD, 2021, p. 122).

\section{Business Schools Issues}

Many business schools moved forward with new or existing building projects. Columbia's construction of a new campus was underway and scheduled to be completed by January 2022 (ABLD, 2021, p. 46). Virginia began construction of a new hotel and conference center that will also include office space for faculty and staff (ABLD, 2021, p. 133). Alabama continued work on a new classroom building, scheduled to open in Fall 2021 (ABLD, 2021, p. 4). North Carolina began fundraising for a new building (ABLD, 2021, p. 89). SMU was set to launch a major building project that would require all business school buildings to be vacated. The business library was investigating moving into the nearby music library at the time of their report (ABLD, 2021, p. 106). 
Ticker: The Academic Business Librarianship Review, 6:2 (2021)

https://doi.org/10.3998/ticker.1940

(C)2021 Greg Fleming

Leadership changes continued, despite the pandemic. New deans took charge at Carnegie Mellon, Cornell, Harvard, Maryland, Penn and Toronto (ABLD, 2021, pp. 34, 48, 62, 72, 98, 111). Deans stepped down or announced their departure at Arizona State, Emory, and Michigan (ABLD, 2021, pp. 6, 58, 80). In the case of Emory, it was to become dean at Penn. Dean searches were getting underway at UBC and Texas (ABLD, 2021, pp. 17, 109).

Babson underwent a major leadership reorganization, with the goal of prioritizing student success. Babson also launched the new Arthur M. Blank School for Entrepreneurial Leadership (ABLD, 2021, p. 9). This included a new master's in advanced entrepreneurial leadership program.

Diversity, equity, and inclusion was also a major theme for business school initiatives. Dartmouth named a new assistant dean for diversity, equity, and inclusion (ABLD, 2021, p. 51). UBC joined the Progressive Aboriginal Relations (PAR) program, which aims to continuously improve relations with indigenous peoples (ABLD, 2021, p. 17). Harvard created a chief diversity officer position and developed a racial equity plan (ABLD, 2021, p. 62). Yale established a Council on Racial Equity and implemented a lecture series on race and socio-economic inequality (ABLD, 2021, p. 136).

Many schools launched new programs despite the disruptions of the pandemic. Boston University had planned the launch of an online MBA, which debuted in August 2020. The first cohort was double the planned size, and future enrollment is expected to be high (ABLD, 2021, p. 11). Purdue and Wake Forest also launched online MBA programs, but Purdue also paused its residential MBA courses due to falling enrollment (ABLD, 2021, pp. 104, 112). Purdue will also launch online master's in business analytics, global supply chain management, and human resources management in Fall 2021. Washington University plans to launch online MBA programs in Fall 2021 as well (ABLD, 2021, p. 121).

Northwestern began an MBAi program, a collaboration of the schools of management and engineering that creates a new blended approach to business and technology leadership (ABLD, 2021, p. 92). Students will typically come from STEM backgrounds, and it includes a quarter in residence in San Francisco. Penn State began an online graduate program in taxation (ABLD, 2021, p. 100). Since 2014, the Smeal College of Business at Penn State has grown from four master's degree programs and one graduate certificate to seventeen master's degrees and twelve certificate programs.

Analytics continues to be an area of growth. Wisconsin began a new Master of Science program and Western started a Master of Management in Analytics (ABLD, 2021, pp. 125, 129). Penn launched a number of new programs, including AI for Business, Computational Social Science Lab, ESG Analytics Lab, and the Wharton Forensic Analytics Lab (ABLD, 2021, p. 98).

\section{Other Issues Affecting Libraries}

Uncertainty was a consistent theme across all aspects of members' reports. Many members wondered what a new normal would look like or even if there would be a new normal. They were also uncertain about how and when they would return to campus work and if remote work would be an option moving forward. Uncertainty about budgets was also an issue. Budgets are a perennial topic of concern in these reports, but the additional pressures of the pandemic increased this concern for many members.

\section{Bibliography}

Academic Business Library Directors (ABLD). (2021). Year in Review Report 2020/2021. Unpublished report. 